Article

\title{
Effectiveness of Platelet-Rich Fibrin (PRF) Following Mandibular Third Molar Extraction: A Systematic Review
}

\author{
A.F.M. Shakilur Rahman ${ }^{\mathrm{I}, *}$ and Tamiral Jannat ${ }^{2}$ \\ ${ }^{\text {I }}$ Department of Oral and Maxillofacial Surgery, Rajshahi Medical College, Rajshahi 6roo, Bangladesh \\ ${ }^{2}$ Department of Pharmacology and Therapeutics, Sir Salimullah Medical College, Dhaka iıoo, Bangladesh; \\ tamiraljannat@gmail.com \\ ${ }^{*}$ Correspondence: raselblackpearl@gmail.com; Tel.: +880-I70968ı I040
}

Submitted: 25 April 202I; Accepted: 8 July 202I; Published: 5 August 202I

\begin{abstract}
I) Purpose: The employment of platelet-rich fibrin (PRF) in the extracted teeth socket has been shown to aid tissue healing. It also minimizes detrimental consequences. The rationale of this systematic review is to observe the possible association between PRF employment and postoperative consequences following mandibular third molar surgery. (2) Materials and Methods: The following databases were explored electronically (till 28 February 202I): PubMed, Cochrane library, Embase, International Clinical Trials Registry Platform (ICTRP), and Clinical Trials.gov. A manual explore was accomplished on various journals regarding the subject of oral and maxillofacial surgery. The online explore applied the keywords "platelet-rich fibrin or PRF," and "mandibular third molar." To review the efficiency of PRF, the accompanying post-operative consequences were collected: pain, swelling, trismus, inter-incisal distance, analgesic consumption, soft tissue healing, bone healing, socket complications, and periodontal parameters. (3) Results: Just 9 full-text studies out of 26 were comprised of review for qualitative analysis. All of the studies were randomized clinical trials (RCTs), with eight split-mouth designs and one parallel design study. Significant outcomes were usually observed for pain, postoperative swelling, mouth opening, periodontal pocket depth, soft tissue healing, and the incidence of alveolar osteitis or dry sockets, but not constantly. The qualitative scrutiny disclosed that the PRF had no considerable outcome in bone healing. (4) Conclusions: Local administration of PRF is a practical way of alleviating pain, trismus, oedema, and enhancing soft tissue healing following mandibular third molar extraction. PRF tends to have no function in bone healing following extraction. More controlled clinical trials and RCTs are necessitating exploring the end results of PRF following mandibular third molar extraction.
\end{abstract}

Keywords: extraction; mandibular third molar; platelet-rich fibrin (PRF)

How to cite: Shakilur Rahman, A.F.M.; Jannat, T. Effectiveness of Platelet-Rich Fibrin (PRF) Following Mandibular Third Molar Extraction: A Systematic Review. Timisoara Med. 202I, $202 \mathrm{I}(\mathrm{I})$, 5; doi:I0.35995/tmj202IoIO5.

\section{Introduction}

The frequent surgical intervention carried out by oral and maxillofacial surgeons is the extraction of the mandibular wisdom teeth [I]. Pain, trismus, swelling, inflammation, and alveolar osteitis (AO) are all potential postoperative consequences of the surgical removal of the mandibular third molar [2]. After mandibular 
third molar extraction, platelet-rich plasma (PRP) was reported to minimize pain, inflammation, and $A O$, and also enhance the healing process of both the soft and hard tissue $[3,4]$. PRP placement, on the other hand, is a lengthy method with reduced mechanical properties, which has deterred many surgeons from using it following extractions [5].

In the year 2000, Choukroun pioneered the employment of platelet-rich fibrin (PRF) [6]. In oral and maxillofacial surgeries, PRF has turned into an effective surgical additive. There have been over 500 scientific papers written on this topic up till now. Wisdom teeth surgery, post-extraction alveolar ridge restoration, sinus lift operation, alveolar cleft repair, dental implants, surgical dealing of drug-associated jaw osteonecrosis, and management of oroantral communications are several of the possible utilization of PRF in oral surgeries [7].

PRF refers to a second-generation platelet concentrate. It is produced using a simple, low-cost method that avoids the use of biochemical blood [8]. It is comprised of three major specifications: first and foremost, the existence of platelets and their active growth factors become embedded in the fibrin matrix during the normal polymerization reaction [8]. Secondly, the role of leucocytes and their cytokines helps with an anti-infectious response and immune modulation in the process of healing [9]. Finally, the fibrin matrix architecture's consistency and complexity are provided by normal polymerization without the need for any anticoagulant or gelling product [Io].

PRF stores various growth factors and cytokines in a fibrin mesh structure and eventually releases cytokines during remodeling. Because of its biological ability to augment the tooth socket-healing process, PRF has a broad array of applications in oral surgeries. The intention of this research paper was to look at the current research on the effects of PRF on the socket healing process and the probable concerns after mandibular third molar extraction.

\section{Materials and Methods}

The following databases were searched electronically for the period from January 2015 to February 202I: PubMed, Cochrane library, Embase, International Clinical Trials Registry Platform (ICTRP), and ClinicalTrials.gov. On 28th February 202I, the most recent search was conducted. A manual search was conducted for various journals regarding the subject of oral and maxillofacial surgery. In the electronic databases explored, we applied the keywords "platelet-rich fibrin or PRF," and "mandibular third molar."

Both randomized clinical trials (RCTs) and controlled clinical trials comparing the impact of PRF usage on freshly extracted tooth sockets after removal of the mandibular third molars versus natural socket healing were included in this study. The English-language-based articles were only included. The exclusion criteria included retrospective studies, case studies, case reports, experimental studies, in vitro studies and review articles. Studies that correlated PRF as a socket filling with other biologic substances, studies of more than six years, and studies that focused at how PRF acted in extraction sockets for teeth other than mandibular third molars were also excluded.

Researchers, publication year, the nation of origin, design of the study, mean age, age range, male-female ratio, respondents, tooth angulation, bone removal, co-interventions, follow-up time, outcome variables, evaluation process, and PRF effects were all extracted for each report (if available). To assess the impact of PRF, the accompanying post—operative consequences were collected: pain, swelling, trismus (maximum inter-incisal opening), AO, and osteoblastic response. The data were compiled by two reviewers who individually analyzed the papers shown in the study. The reviewers' disputes were settled by agreement. 


\section{Results}

The manual and computerized scans showed 159 papers, I03 of which were duplicates and had to be removed. The summaries of the 56 papers were reviewed, and the authors read the entire text of the relevant studies for possible inclusion. A total of 26 trials were found in the following databases: PubMed $(n=15)$, Cochrane library $(n=26)$, Embase $(n=\mathrm{II})$, ICTRP $(n=3)$, and Clinical Trials.gov $(n=\mathrm{I})$. Among these trials, four trials were found in both the PubMed and Embase databases. There were three clinical trials found in other sources, such as The Saudi Journal for Dental Research $(n=\mathrm{I})$, IJSS Journal of Surgery $(n=\mathrm{I})$, and Annals of Maxillofacial Surgery $(n=\mathrm{I})$. Just nine full-text studies out of 26 were found to meet the inclusion criteria and were reviewed for qualitative analysis in this study. The study collection and analysis processes are depicted in Figure I.
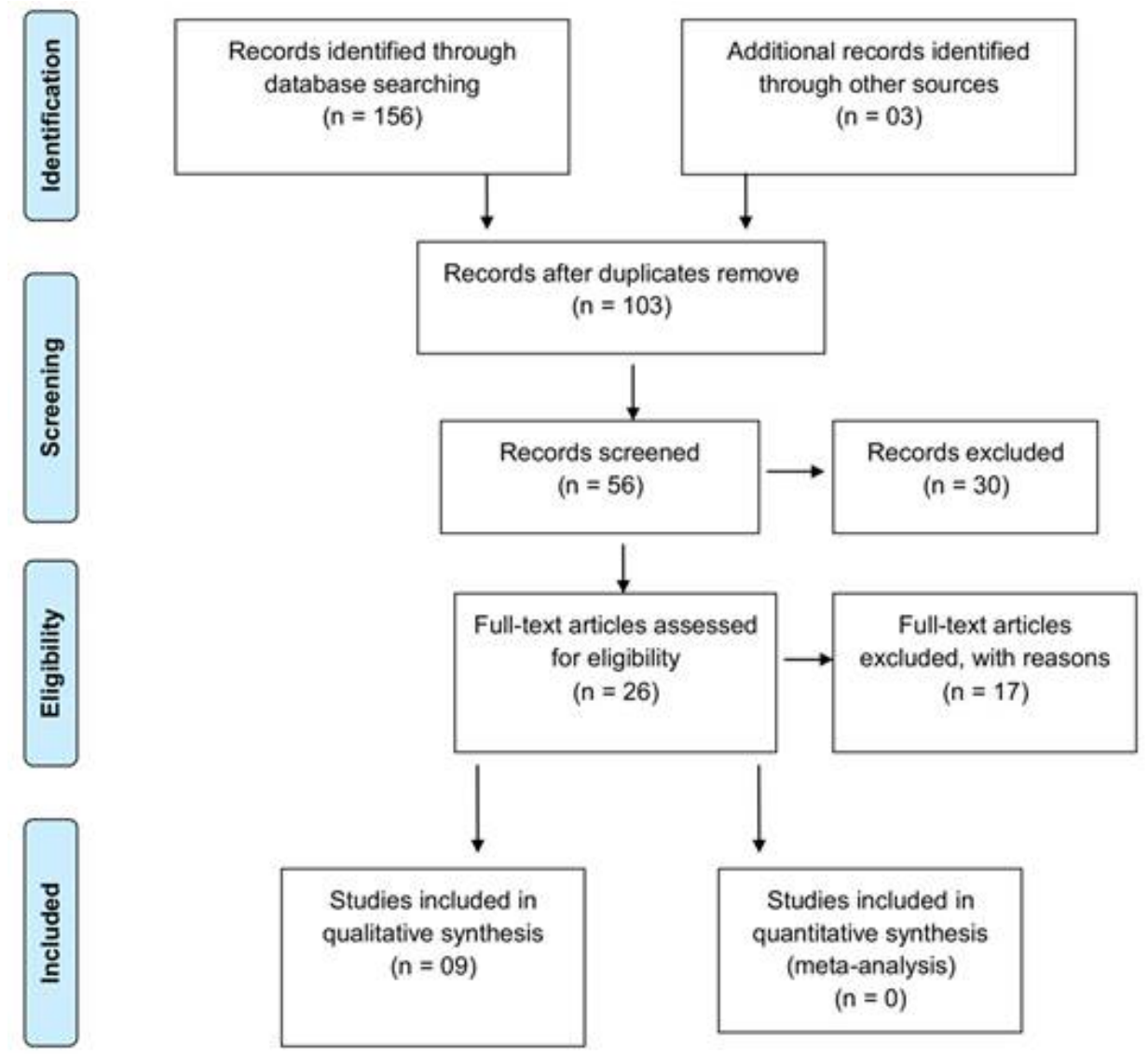

Figure I. PRISMA flow diagram.

All of the studies were RCTs, with eight split-mouth studies and one parallel design study. The publication years of these trials ranged from 20I5 to 202I. The studies included were conducted in five different countries: India $(n=3)$, Turkey $(n=3)$, Egypt $(n=\mathrm{I})$, Japan $(n=\mathrm{I})$, and Brazil $(n=\mathrm{I})$ (Table I). Pain, swelling, trismus, inter-incisal distance, periodontal pocket depth (PPD), analgesic consumption, soft tissue healing, bone healing, socket complications, and periodontal parameters were all outcome variables in these studies (Table 2). Postoperative pain was assessed in eight trials [II-I8]. Postoperative swelling was evaluated in six trials [II,I2,I4,I6-I8]. The socket complications [ $[\mathrm{I} 3]$, and periodontal parameters [I7] were assessed in one clinical trial. The inter-incisal distance or trismus [II,I8], and analgesic consumption [13,I8] were assessed in two trials. Soft tissue healing $[\mathrm{I} 3, \mathrm{I} 5, \mathrm{I} 8]$ and PPD [II,I8,19] were assessed in three studies. The bone healing evaluation was reported in four trials [11,I5,I8,I9]. 
Table I. The included studies' features and patient demographic records with PRF preparation method.

\begin{tabular}{|c|c|c|c|c|c|c|c|c|c|}
\hline \multirow{2}{*}{ Authors, Year } & \multirow{2}{*}{ Country } & \multirow{2}{*}{ Study Design } & \multirow{2}{*}{$\begin{array}{l}\text { Participants } \\
\text { (n) }\end{array}$} & \multirow{2}{*}{$\begin{array}{l}\text { Mean Age (Age } \\
\text { Range in Years) }\end{array}$} & \multirow{2}{*}{$\begin{array}{l}\text { M:F } \\
\text { Ratio }\end{array}$} & \multicolumn{2}{|c|}{ Cases (n) } & \multirow{2}{*}{ Follow Up } & \multirow{2}{*}{ PRF Preparation } \\
\hline & & & & & & PRF & Control & & \\
\hline $\begin{array}{l}\text { Kumar et al., } \\
2015[\mathrm{II}]\end{array}$ & India & RCT (Parallel design) & $3 \mathrm{I}$ & 26.1 yr (19-35) & NR & 16 & I5 & $\begin{array}{l}\text { At ist POD, ist month, and 3rd } \\
\text { month }\end{array}$ & $\begin{array}{l}5 \mathrm{~mL} \text { of venous blood centrifuged } \\
\text { at } 3000 \mathrm{rpm} \text { for Io } \mathrm{min}\end{array}$ \\
\hline Ozgul et al., 2015 [I2] & Turkey & RCT (Split mouth) & 56 & NR (I8-28) & $23: 33$ & 56 & 56 & $\mathrm{I}, 3$, and 7 POD & $\begin{array}{l}\text { Io } \mathrm{mL} \text { of blood, centrifuged at } \\
3000 \mathrm{rpm} \text { for Io } \mathrm{min}\end{array}$ \\
\hline $\begin{array}{l}\text { Baslarli et al., } \\
2015 \text { [19] }\end{array}$ & Turkey & RCT (Split mouth) & 20 & 23.9 yr (19-34) & $7: 13$ & 20 & 20 & FU at ist and 3 rd month of POD. & $\begin{array}{l}9 \mathrm{~mL} \text { of blood, centrifuged at } \\
3000 \mathrm{rpm} \text { for Io min }\end{array}$ \\
\hline $\begin{array}{l}\text { Al-Hamed et al., } \\
2017\left[\mathrm{I}_{3}\right]\end{array}$ & Egypt & RCT (Parallel design) & 47 & $25.24 \pm 7.04(\mathrm{I} 8-48)$ & $\mathrm{I} 3: 34$ & 25 & 25 & FU to one week postoperatively. & $\begin{array}{l}5 \mathrm{~mL} \text { of blood, centrifuged at } \\
3000 \text { rpm for to min }\end{array}$ \\
\hline $\begin{array}{l}\text { Gülşen et al., } \\
2017 \text { [14] }\end{array}$ & Turkey & RCT (Split mouth) & 30 & $20.03(17-27)$ & 21:9 & 30 & 30 & $\begin{array}{l}\text { FU at } 6 \text { and I2 } \mathrm{h} \text {, followed by Ist, } \\
\text { 2nd, } 3 \mathrm{rd} \text {, and } 7 \text { th POD. }\end{array}$ & $\begin{array}{l}30 \mathrm{~mL} \text { of blood, centrifuged at } \\
3000 \mathrm{rpm} \text { for Io min }\end{array}$ \\
\hline Ritto et al., 2019. [I5] & Brazil & $\begin{array}{l}\text { RCT (Double blind } \\
\text { split mouth) }\end{array}$ & 17 & 2I.8 yr (I6-29) & I0:7 & I7 & 17 & $\begin{array}{l}\mathrm{FU} \text { at } 24 \mathrm{~h}, 72 \mathrm{~h} \text {, and } 7 \text { days after } \\
\text { the procedure. Bone healing } \\
\text { evaluation was done after surgery } \\
\text { and } 3 \text { months postoperatively. }\end{array}$ & $\begin{array}{l}\text { Io } \mathrm{mL} \text { of blood, centrifuged at } \\
2700 \mathrm{rpm} \text { for } \mathrm{I} 2 \mathrm{~min}\end{array}$ \\
\hline $\begin{array}{l}\text { Miyamoto et al., } \\
2020[16]\end{array}$ & Japan & RCT (Split mouth) & 32 & $29.1(20-51)$ & $\mathrm{I} 4: \mathrm{I} 8$ & 32 & 32 & FU to 7 days postoperatively. & $\begin{array}{l}40 \mathrm{~mL} \text { of blood, centrifuged at } \\
400 \mathrm{~g}(3000 \mathrm{rpm}) \text { for Io min }\end{array}$ \\
\hline Sybil et al., 2020 [17] & India & RCT (Split mouth) & 25 & 32.3 yr (18-55) & I4:II & 25 & 25 & $\begin{array}{l}\text { FU at Ist day, } 3 \text { rd day, ist week, ist, } \\
\text { 3rd, and 6th month }\end{array}$ & $\begin{array}{l}\text { Io } \mathrm{mL} \text { of blood, centrifuged at } \\
\text { 30oo rpm for Io min. }\end{array}$ \\
\hline $\begin{array}{l}\text { Gupta et al., } \\
2021[18]\end{array}$ & India & RCT (Split mouth) & 20 & NR (I8-35) & $8: 12$ & 20 & 20 & $\begin{array}{l}\text { Pain, swelling, soft tissue healing, } \\
\text { trismus assessed on the Ist, 3rd,7th } \\
\text { day follow-up. Ist, 3rd, and 6th } \\
\text { month of follow-up: bone } \\
\text { healing assessed }\end{array}$ & $\begin{array}{l}\text { Io } \mathrm{mL} \text { of blood, centrifuged at } \\
\text { I5Oo } \mathrm{rpm} \text { for } \mathrm{I} 4 \mathrm{~min} \text {. }\end{array}$ \\
\hline
\end{tabular}

$\mathrm{RCT}=$ Randomized controlled trial, $\mathrm{NR}=$ Not reported, $\mathrm{FU}=$ Follow up, $\mathrm{RPM}=$ Rotations per minute, $\mathrm{CBC}$ = Cone beam computed tomography, $\mathrm{POD}=\mathrm{Postoperative} \mathrm{day}$. 
Table 2. Supplementary features of included studies with outcome variables and PRF effects.

\begin{tabular}{|c|c|c|c|c|c|c|}
\hline $\begin{array}{l}\text { Authors, } \\
\text { Year }\end{array}$ & Tooth Angulation & $\begin{array}{l}\text { Bone } \\
\text { Removal }\end{array}$ & Co-Interventions & Outcome Variables & Assessment Procedure & Effects of PRF as Stated in the Analysis \\
\hline $\begin{array}{l}\text { Kumar et al., } \\
\text { 20I5 [II] }\end{array}$ & $\begin{array}{l}\text { Horizontal or mesial } \\
\text { impaction }\end{array}$ & Yes & $\begin{array}{l}\text { Amoxicillin }(500 \mathrm{mg} \times 3) \text {, } \\
\text { metronidazole }(400 \mathrm{mg} \times 3) \text {, } \\
\text { Combination of aceclofenac } \\
\text { with paracetamol }(2 \text { times } \\
\text { daily), and chlorhexidine }(3 \\
\text { times daily) for } 3 \text { days } \\
\text { following surgery }\end{array}$ & $\begin{array}{l}\text { Pain, swelling, } \\
\text { inter-incisal distance, } \\
\text { PPD, and bone } \\
\text { formation. }\end{array}$ & $\begin{array}{l}\text { Pain and swelling was evaluated by the } \\
\text { method of Pasqualini et al. [20]. } \\
\text { The inter-incisal distance was recorded } \\
\text { by a divider and ruler. } \\
\text { The PPD and bone formation was } \\
\text { assessed by radiograph (IOPAR and } \\
\text { OPG). }\end{array}$ & $\begin{array}{l}\text { Pain }(p=0.017) \text {, swelling }(p=0.022) \text {, and inter-incisal } \\
\text { distance }(p=0.040) \text { were found to be reduced in the PRF } \\
\text { group on the Ist POD. PPD was statistically considerable in } \\
\text { both the PRF ( } p<0.001) \text { and control }(p=0.014) \text { groups } \\
\text { three months subsequent to surgery. } \\
\text { At three months following surgery, the difference in bone } \\
\text { density values was not statistically meaningful }(p>0.05) \text {. } \\
\text { The postoperative use of PRF lightens the effect } \\
\text { immediately, maintains less postoperative pocket depth, and } \\
\text { accelerates bone formation. }\end{array}$ \\
\hline $\begin{array}{l}\text { Ozgul et al., } \\
2015[12]\end{array}$ & $\begin{array}{l}\text { Horizontal, mesial, } \\
\text { or vertical impaction }\end{array}$ & No & $\begin{array}{l}\text { Amoxicillin ( } 1000 \mathrm{mg} \times 2) \text { as } \\
\text { an antibiotic, paracetamol } \\
(500 \mathrm{mg} \times 3) \text {, and } \\
\text { chlorhexidine ( } 3 \text { times daily) } \\
\text { mouth wash for7 days after } \\
\text { extraction. }\end{array}$ & Pain and swelling. & $\begin{array}{l}\text { Pain evaluated by VAS. } \\
\text { With a flexible ruler and a horizontal } \\
\text { with vertical reference, the swelling was } \\
\text { assessed. }\end{array}$ & $\begin{array}{l}\text { On the third day following surgery, the control side } \\
\text { (without PRF) revealed more swelling }(p<0.05) \text {. } \\
\text { There were no statistically meaningful variations between } \\
\text { the groups in terms of pain }(p>0.05) \text {. PRF shows great } \\
\text { promise in reducing postoperative swelling after surgery. }\end{array}$ \\
\hline $\begin{array}{l}\text { Baslarli et al., } \\
2015 \text { [I9] }\end{array}$ & $\begin{array}{l}\text { Vertical or mesial } \\
\text { impaction }\end{array}$ & No & $\begin{array}{l}\text { Amoxicillin }(\text { Iooo } \mathrm{mg} \times 2) \\
\text { and Naproxen }(550 \mathrm{mg} \times 3) \\
\text { sodium was given fors days } \\
\text { postoperatively. }\end{array}$ & $\begin{array}{l}\text { Osteoblastic activity } \\
\text { of post extraction } \\
\text { mandibular } 3 \text { rd } \\
\text { molar socket. }\end{array}$ & $\begin{array}{l}\text { The osteoblastic activity was assessed } \\
\text { by OPG and bone scintigrams. } \\
\text { PPD was clinically evaluated by using a } \\
\text { Michigan periodontal probe. The } \\
\text { study specified a probing depth of a } \\
\text { minimum of } 4 \text { mm as a condition for } \\
\text { the diagnosis of periodontal pathology. }\end{array}$ & $\begin{array}{l}\text { At } 30 \text { and } 90 \text { POD, PRF may not result in improved bone } \\
\text { healing in impacted mandibular third molar extraction } \\
\text { sockets. } \\
\text { PPD values were not also statistically significant }(p<0.01) \text {. }\end{array}$ \\
\hline $\begin{array}{l}\text { Al-Hamed } \\
\text { et al., } 2017 \text { [13] }\end{array}$ & $\begin{array}{l}\text { Mesioangular, } \\
\text { horizontal, vertical, } \\
\text { and distoangular } \\
\text { impacted } \\
\text { mandibular 3rd } \\
\text { molar. }\end{array}$ & Yes & $\begin{array}{l}\text { Amoxicillin } 500 \text { mg six hourly } \\
\text { a day for five days, Ibuprofen } \\
400 \text { mg thrice a day as an } \\
\text { analgesic the first day of } \\
\text { surgery, and chlorhexidine } \\
\text { mouthwash } 12 \text { hourly a day } \\
\text { for seven days. }\end{array}$ & $\begin{array}{l}\text { Pain, analgesic } \\
\text { consumption, soft } \\
\text { tissue healing and } \\
\text { socket complications }\end{array}$ & $\begin{array}{l}\text { The pain was evaluated by VAS. } \\
\text { Following seven days of surgery, soft } \\
\text { tissue wound healing was assessed } \\
\text { using Landry et al. [2I] procedure. } \\
\text { The Socket complications were studied } \\
\text { following the instructions in the study } \\
\text { of Cheung et al. [22]. }\end{array}$ & $\begin{array}{l}\text { During the fifth, sixth, and seventh POD, patients reported } \\
\text { significantly less pain ( } p=0.04 \mathrm{I}, 0.03 \mathrm{I}, 0.005 \\
\text { correspondingly) in the PRF group. } \\
\text { Additionally, patients in the PRF group had significantly } \\
\text { reduced consumption of analgesics for the second, third, } \\
\text { sixth, and seventh days ( } p=0.019,0.039,0.045 \text { and } 0.020 \text {, } \\
\text { respectively). } \\
\text { The PRF successfully decreased the frequency of AO ( } p= \\
\text { o.037). } \\
\text { There was no substantial difference in soft tissue healing } \\
\text { between the PRF and control groups }(p=0.187) \text {. }\end{array}$ \\
\hline
\end{tabular}


Table 2. Cont

\begin{tabular}{|c|c|c|c|c|c|c|}
\hline $\begin{array}{l}\text { Authors, } \\
\text { Year }\end{array}$ & Tooth Angulation & $\begin{array}{l}\text { Bone } \\
\text { Removal }\end{array}$ & Co-Interventions & Outcome Variables & Assessment Procedure & Effects of PRF as Stated in the Analysis \\
\hline $\begin{array}{l}\text { Gülşen et al., } \\
2017[\mathrm{I} 4]\end{array}$ & $\begin{array}{l}\text { Third molars in the } \\
\text { Class I, Level B } \\
\text { position (Pell and } \\
\text { Gregory), and } \\
\text { vertical positions } \\
\text { (Winter). }\end{array}$ & Yes & $\begin{array}{l}\text { Following surgery, patients } \\
\text { were given amoxicillin (Iooo } \\
\mathrm{mg} \times 2 \text { ) for five days), o.2\% } \\
\text { chlorhexidine mouthwash }(2 \\
\text { times daily) for seven days, } \\
\text { and, if needed, } \\
\text { acetaminophen (5oo } \mathrm{mg} \times 4 \text { ) } \\
\text { per day. }\end{array}$ & $\begin{array}{l}\text { Postoperative pain } \\
\text { and oedema. }\end{array}$ & $\begin{array}{l}\text { Patients' pain was measured with VAS } \\
\text { and VRS. } \\
\text { Using a flexible tape-measure approach } \\
\text { in three directions to assess } \\
\text { postoperative swelling. }\end{array}$ & $\begin{array}{l}\text { PRF was similarly efficient in diminishing postoperative } \\
\text { pain and swelling in lower third molar surgery }(p>0.05) \text {. }\end{array}$ \\
\hline $\begin{array}{l}\text { Ritto et al., } \\
2019 \text { [15] }\end{array}$ & $\begin{array}{l}\text { Bilateral similar } \\
\text { mandibular } 3 \text { rd } \\
\text { molar position } \\
\text { according to Pell and } \\
\text { Gregory } \\
\text { classification }\end{array}$ & Yes & $\begin{array}{l}8 \mathrm{mg} \text { of dexamethasone } \mathrm{I} \mathrm{h} \\
\text { prior to surgery; } 400 \mathrm{mg} \\
\text { ibuprofen and } 750 \mathrm{mg} \\
\text { acetaminophen } 6 \text { hourly for } 5 \\
\text { days following surgery. }\end{array}$ & $\begin{array}{l}\text { Pain, bone healing, } \\
\text { and soft tissue } \\
\text { evaluation. }\end{array}$ & $\begin{array}{l}\text { Patients' pain was assessed with VAS. } \\
\text { Bone healing was evaluated by CBCT. } \\
\text { Two parameters were employed to } \\
\text { appraise soft tissue status: (I) } \\
\text { periodontal probing just distal to the } \\
\text { mandibular second molar; and (2) soft } \\
\text { tissue healing by Landry et al. [2I] } \\
\text { healing assessment procedure. }\end{array}$ & $\begin{array}{l}\text { PRF treatment increased bone density, which was } \\
\text { significantly greater in the experimental group }(p=0.007) \text {. } \\
\text { The statistical difference showed without significance in } \\
\text { terms of pain or soft tissue healing }(p>0.05) \text {. } \\
\text { There was evidence of positive bone healing in the PRF } \\
\text { group. }\end{array}$ \\
\hline $\begin{array}{l}\text { Miyamoto } \\
\text { et al., } \\
2020[16]\end{array}$ & $\begin{array}{l}\text { Mandibular 3rd } \\
\text { molar position } \\
\text { according to Pell and } \\
\text { Gregory } \\
\text { classificationiA-17 } \\
\text { cases, } 1 \text { B-5 cases, } \\
\text { 2A-Is cases, 2B-23 } \\
\text { cases, 2C-4 cases. }\end{array}$ & Yes & $\begin{array}{l}\text { Amoxicillin } 750 \mathrm{mg} / \mathrm{day} \text { was } \\
\text { used as an antibiotic for four } \\
\text { days, and } 60 \mathrm{mg} \text { of } \\
\text { loxoprofen sodium hydrate } \\
\text { was used as an analgesic. }\end{array}$ & Pain and swelling. & $\begin{array}{l}\text { Pain assessment was done by VAS. } \\
\text { Swelling was assessed clinically. }\end{array}$ & $\begin{array}{l}\text { VAS difference was discovered to be significant at the } 3 \text { rd and } \\
\text { 4th POD between the PRF and control group }(p<0.05) \text {. } \\
\text { It was concluded that the PRF had short-term efficacy for } \\
\text { pain relief immediately after surgery (within } 7 \text { th POD). }\end{array}$ \\
\hline
\end{tabular}


Table 2. Cont

\begin{tabular}{|c|c|c|c|c|c|c|}
\hline $\begin{array}{l}\text { Authors, } \\
\text { Year }\end{array}$ & Tooth Angulation & $\begin{array}{l}\text { Bone } \\
\text { Removal }\end{array}$ & Co-Interventions & Outcome Variables & Assessment Procedure & Effects of PRF as Stated in the Analysis \\
\hline $\begin{array}{l}\text { Sybil et al., } \\
2020[17]\end{array}$ & $\begin{array}{l}\text { Horizontal } \\
\text { impaction-20, } \\
\text { Mesioangular } \\
\text { impaction-30 }\end{array}$ & Yes & NR & $\begin{array}{l}\text { Four surgical (pain, } \\
\text { tenderness, } \\
\text { sensitivity, and } \\
\text { edema) and four } \\
\text { periodontal (Plaque } \\
\text { Index, SBI, CAL, } \\
\text { and PD) parameters. }\end{array}$ & $\begin{array}{l}\text { The pain was assessed by VAS. The SBI } \\
\text { was graded on a numerical scale (o- } 5 \text { ). } \\
\text { A periodontal probe was used to } \\
\text { determine CAL and PD in millimeters. } \\
\text { Bone height was measured by an } \\
\text { IOPAR. }\end{array}$ & 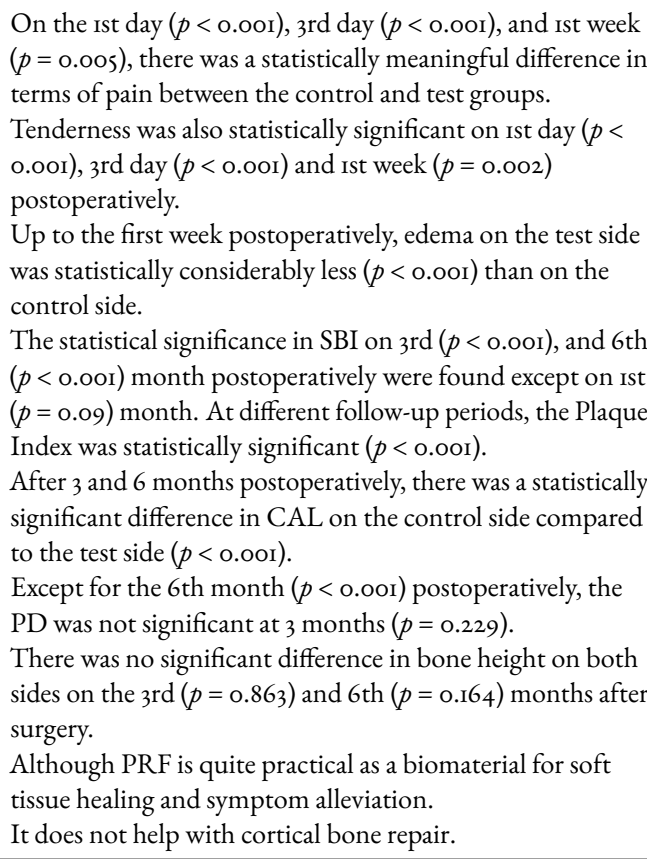 \\
\hline $\begin{array}{l}\text { Gupta et al., } \\
\text { 202I [18] }\end{array}$ & $\begin{array}{l}\text { Pederson difficulty } \\
\text { index: minimal to } \\
\text { moderate difficulty } \\
\text { bilateral mandibular } \\
\text { 3rd molar impactions }\end{array}$ & Yes & $\begin{array}{l}\text { Analgesics were administered } \\
\text { postoperatively. }\end{array}$ & $\begin{array}{l}\text { Pain, swelling, } \\
\text { trismus, soft tissue } \\
\text { healing, and bone } \\
\text { healing. }\end{array}$ & $\begin{array}{l}\text { Pain by VAS. } \\
\text { An evaluation of soft tissue healing } \\
\text { was performed by the Landry et al. [2I] } \\
\text { scale. Linear measurements in two } \\
\text { directions were taken on each side after } \\
\text { the surgery to assess the level of } \\
\text { postoperative swelling. } \\
\text { Trismus was evaluated by measuring } \\
\text { the maximum inter-incisal distance. } \\
\text { Bone healing was assessed by IOPAR. }\end{array}$ & $\begin{array}{l}\text { An analysis of } 3 \text { rd POD follow-up: pain, swelling, trismus, } \\
\text { and soft tissue healing reported statistically significant ( } p \\
\text {-values were o.oo8, o.031, o.ooor, o.o5, respectively). When } \\
\text { PRF was administered, the consumption of analgesics was } \\
\text { less than expected }(p=0.004) \text {. } \\
\text { Significant improvement }(p<0.05) \text { in the outcomes of bone } \\
\text { healing in the PRF sites in the Ist, 3rd and 6th-month } \\
\text { follow-up had been observed. }\end{array}$ \\
\hline
\end{tabular}

VAS = Visual analogue scale, $\mathrm{VRS}=$ Verbal scale, $\mathrm{CBCT}=$ Cone beam computed tomography, $\mathrm{PRF}=$ Platelet rich fibrin, $\mathrm{POD}=$ Postoperative day, IOPAR $=$ Intraoral periapical radiograph, $\mathrm{NR}=$ Not reported, $\mathrm{PI}=$ Plaque index, $\mathrm{SBI}=$ Sulcus bleeding index, $\mathrm{CAL}=$ Clinical attachment level, $\mathrm{PD}=$ Probing depth. 


\section{PRF Effect on Postoperative Pain}

Postoperative pain was assessed in all trials except one. Pain was assessed using a visual analogue scale (VAS) ranging from either o (no pain) to Io (most severe pain) [I5,I8] or o (no pain) to Ioo (most severe pain) [12,I4]. It was also assessed by a verbal scale (VRS) [I4] ranging from o (painless) to 5 (unendurable pain). The statistical significance of pain alleviation was found between PRF and non-PRF groups in five trials [11,13,16-18] except three [I2,I4,I5]. The exceptions were conducted by Ozgul et al. [I2], Gülşen et al. [I4], and Ritto et al. [I5] (Table 3 ).

\section{PRF Effect on Postoperative Swelling}

Swelling was assessed postoperatively in two directions using a flexible tape-measure approach: one is from the angle of the mouth to the tragus of the ear and the other is from the lateral canthus of the eye to the angle of the mandible [I2,I8]. Gülşen et al. [14] defined facial swelling using distance measurements from the angle of the mandible to the angle of the mouth, from the tragus to the angle of the mouth, and from the tragus to the lateral canthus of the eye with a flexible ruler. The difference between preoperative and postoperative mean values of either two [12,18] or three [14] distances was recorded to determine the swelling measurement. The postoperative swelling was statistically significant between PRF and the control group on Ist $(p=0.022)$ [II] and 3 rd $(p<0.05, p=0.03 \mathrm{I})[\mathrm{I} 2, \mathrm{I} 8]$ day. The PRF group experienced swelling relief a little earlier, but the difference was not statistically considerable $(p>0.05)$ and the PRF group had no meaningful effect on swelling relief [14,I6]. The PRF effect on postoperative swelling is detailed in Table 4.

\section{PRF Effect on Soft Tissue Healing}

The soft tissue wound healing was assessed using the scale reported by Landry et al. [2I]. This is a 5-point evaluation scale, and the higher the number, the greater the healing is. It includes tissue color, palpation reaction, granulation tissue, epithelialization of the incision margin, and the presence of pus. Gupta et al. [I8] reported statistical significance $(p<0.05$ ) between the PRF and the control group (without PRF) regarding soft tissue healing on the third and seventh postoperative days. However, the PRF group revealed no statistical significance $(p=0.187, p>0.05)$ in soft tissue healing in other trials $\left[{ }_{13}, 15\right]$. Soft tissue healing measurements of the included studies are detailed in Table 5 . 
Table 3. The results of included studies considered in the analysis of pain.

\begin{tabular}{|c|c|c|c|c|c|c|c|}
\hline \multirow{2}{*}{ Authors, Year } & \multirow{2}{*}{ Procedure of Measurement } & \multirow{2}{*}{ Statistic } & \multicolumn{5}{|l|}{ Results } \\
\hline & & & \multicolumn{2}{|c|}{ Follow-Up Periods } & \multirow{2}{*}{$\begin{array}{l}\text { PRF } \\
\text { I4 }(87.5 \%)\end{array}$} & \multirow{2}{*}{$\begin{array}{l}\text { Control } \\
6(40 \%)\end{array}$} & \multirow[t]{2}{*}{$p$-Value } \\
\hline \multirow{5}{*}{ Kumar et al., 20Is [II] } & \multirow{5}{*}{ VAS according to Pasqualini et al. } & \multirow{5}{*}{ Proportion } & & Mild & & & \\
\hline & & & Ist POD & Slight & $2(\mathrm{I} 2.5 \%)$ & $6(40 \%)$ & $0.017^{\ddagger}$ \\
\hline & & & & Severe & $\circ(\circ \%)$ & $3(20 \%)$ & \\
\hline & & & Ist month & & NR & NR & NR \\
\hline & & & $3^{\text {rd month }}$ & & NR & NR & NR \\
\hline \multirow{3}{*}{ Ozgul et al., 20I5 [I2] } & VAS (o-Ioo) score & \multirow{3}{*}{ Mean (SD) } & Ist POD & & $47.16(30.59)$ & $42.84(29.77)$ & $0.413^{\ddagger}$ \\
\hline & "o" = No pain & & 3 rd POD & & $25.5(29.95)$ & $26.48(30.36)$ & $0.296 \ddagger$ \\
\hline & "Iоо" = Worst pain & & 7 th POD & & I0.2I (I0.2I) & $9.4 \mathrm{I}(\mathrm{I} 6.57)$ & $0.503^{\ddagger}$ \\
\hline \multirow{6}{*}{ Al-Hamed et al., 2017 [13] } & \multirow{6}{*}{$\begin{array}{l}\text { VAS (o-10) score } \\
\text { "o" = No pain } \\
\text { "Io" = Worst pain }\end{array}$} & \multirow{6}{*}{ Mean $(\mathrm{SD})$} & 2nd POD & & $3.08(2.75)$ & $4.24(2.86)$ & $0.152^{\ddagger}$ \\
\hline & & & $3 \mathrm{rd} \mathrm{POD}$ & & $\mathrm{I.92}(2.27)$ & $2.88(2.36)$ & $0.078^{\ddagger}$ \\
\hline & & & 4th POD & & $\mathrm{I.20}(\mathrm{I} .73)$ & $2.16(2.37)$ & $0.057^{\ddagger}$ \\
\hline & & & sth POD & & $0.80(\mathrm{I} .55)$ & $\mathrm{I} .28(\mathrm{I} .54)$ & $0.041^{\ddagger}$ \\
\hline & & & 6th POD & & $0.48(\mathrm{I} .5)$ & $0.72(\mathrm{I} .4)$ & $0.031 \mp$ \\
\hline & & & 7th POD & & $\mathrm{o}(\mathrm{o})$ & $0.52(\mathrm{I} .4 \mathrm{I})$ & $0.005^{\ddagger}$ \\
\hline \multirow{4}{*}{ Gülşen et al., 2017 [I4] } & VAS and VRS & \multirow{4}{*}{ Mean (SD) } & $6 \mathrm{~h}$ & & $42.7(27.5)$ & $40.0(26.3)$ & $0.706^{\ddagger}$ \\
\hline & VAS (o-10o) score & & $\mathrm{I} 2 \mathrm{~h}$ & & $36 . I(28.5)$ & $30.0(28.9)$ & $0.374^{\ddagger}$ \\
\hline & "o" = Painless & & ist POD & & $25.0(26.3)$ & $20.9(26.1)$ & $0.398^{\ddagger}$ \\
\hline & "Iоо" = Most obnoxious pain. & & 2nd POD & & $15.8(20.9)$ & $\mathrm{I} 3.8(\mathrm{I} 8.4)$ & $0.655 \ddagger$ \\
\hline \multirow{3}{*}{ Ritto et al., 2019 [Is] } & VAS (o-Io) score & \multirow{3}{*}{ Mean (SD) } & & & $3.00(2.8 \mathrm{I})$ & & $0.233 \div$ \\
\hline & "o" = Painless & & 3rd POD & & $2.85(2.17)$ & $\begin{array}{l}3.90(2.9) \\
3.1 \mathrm{II}(2.6 \mathrm{I})\end{array}$ & $0.750^{0 .}$ \\
\hline & "Iо" = Most agonizing of pain & & 7th POD & & $1.53(2.50)$ & $2 . \mathrm{II}(3.04)$ & $0.547^{\ddagger}$ \\
\hline Miyamoto et al., 2020 [16] & $\begin{array}{l}\text { VAS (o-IOo) score } \\
\text { "o" = No pain } \\
\text { "Ioo" = Worst pain }\end{array}$ & Mean & \multicolumn{2}{|c|}{ For 7 days postoperatively } & \multicolumn{3}{|c|}{$\begin{array}{l}\text { The mean VAS values were detailed in the figure with statistical significance } \\
(p<0.05) \text { on days } 3 \text { and } 4 \text { postoperatively. }\end{array}$} \\
\hline \multirow{3}{*}{ Sybil et al., $2020[\mathrm{I} 7]$} & VAS (o-Io) score & \multirow{3}{*}{ Mean (SD) } & \multirow{3}{*}{\multicolumn{2}{|c|}{$\begin{array}{l}\text { Ist POD } \\
\text { 3rd POD } \\
\text { 7th POD }\end{array}$}} & $0.80(0.764)$ & $2.08(\mathrm{I} .358)$ & $p<0.00 I^{\ddagger}$ \\
\hline & "o" = Painless & & & & $0.56(0.712)$ & I.8 (I.04I) & $p<0.001 \ddagger$ \\
\hline & "Iо" = Worst pain & & & & $3.24(\mathrm{I} .422)$ & $4.48(1.584)$ & $0.005^{\ddagger}$ \\
\hline \multirow{3}{*}{ Gupta et al., 202I [18] } & VAS (o-Io) score & \multirow{3}{*}{ Mean $(S D)$} & & & & & \\
\hline & "o" = Painless & & $3 \mathrm{rd} P O D$ & & 2.6 (I.62) & 3.8 (I.02) & $0.008^{\ddagger}$ \\
\hline & "IO" = Severe pain & & & & $0.1(0.3)$ & $0.45(0.66)$ & $0.04^{\ddagger}$ \\
\hline
\end{tabular}

VAS = Visual analogue scale, VRS = Verbal scale, $\mathrm{POD}=$ Postoperative day, $\mathrm{SD}=$ Standard deviation, ${ }^{\ddagger} p<0.05$, Statistically significant, ${ }^{\ddagger} p>0.05$, Statistically non-significant. 
Table 4. The result of studies considered in the analysis of postoperative swelling.

\begin{tabular}{|c|c|c|c|c|c|c|c|}
\hline \multirow{2}{*}{ Authors, Year } & \multirow{2}{*}{ Procedure of Measurement } & \multirow{2}{*}{$\begin{array}{l}\text { Postoperative } \\
\text { Follow-Up Periods }\end{array}$} & \multicolumn{5}{|c|}{ Results } \\
\hline & & & \multicolumn{2}{|c|}{ Statistic } & PRF & Control & $p$-Value \\
\hline $\begin{array}{l}\text { Kumar et al., } \\
\text { 2OIS [II] }\end{array}$ & VAS according to Pasqualini et al. method. & $\begin{array}{l}\text { Ist day, ist month, } \\
\text { 3rd month }\end{array}$ & Proportion & $\begin{array}{l}\text { Mild } \\
\text { Slight } \\
\text { Severe }\end{array}$ & $\begin{array}{l}\mathrm{I} 3(8 \mathrm{I} .3 \%) \\
3(\mathrm{I} 8.8 \%) \\
\mathrm{o}(\mathrm{o} \%)\end{array}$ & $\begin{array}{l}7(46.7 \%) \\
5(33.3 \%) \\
3(20.0 \%)\end{array}$ & $0.022 \ddagger$ \\
\hline \multirow{3}{*}{$\begin{array}{l}\text { Ozgul et al., } \\
\text { 20I5 [12] }\end{array}$} & \multirow{3}{*}{$\begin{array}{l}\text { Using a flexible tape-measure approach in two directions } \\
\qquad(\mathrm{AB} \text { and } \mathrm{CD}) \text {. }^{*}\end{array}$} & \multirow{3}{*}{ Ist, 3rd, and 7 th POD } & \multicolumn{5}{|c|}{ Mean (SD) } \\
\hline & & & $\mathrm{CD}$ & $\begin{array}{l}\text { Ist POD } \\
\text { 3rd POD } \\
\text { 7th POD }\end{array}$ & $\begin{array}{l}3.28(3.02) \\
1.83(2.52) \\
0.57(1.87)\end{array}$ & $\begin{array}{l}4.64(4.27) \\
3.62(3.5 \mathrm{I}) \\
0.73(\mathrm{I} .89)\end{array}$ & $\begin{array}{l}0.041^{\ddagger} \\
0.001^{\ddagger} \\
0.634^{\ddagger}\end{array}$ \\
\hline & & & $\mathrm{AB}$ & $\begin{array}{l}\text { Ist POD } \\
\text { 3rd POD } \\
\text { 7th POD }\end{array}$ & $\begin{array}{l}5.19(8.12) \\
3.42(6.55) \\
0.82(3.8 \mathrm{I})\end{array}$ & $\begin{array}{l}5.92(7.42) \\
4.0(6.42) \\
1.28(3.95)\end{array}$ & $\begin{array}{l}0.306^{\ddagger} \\
0.589^{\ddagger} \\
0.061^{\ddagger}\end{array}$ \\
\hline \multirow{4}{*}{$\begin{array}{l}\text { Gülşen et al., } \\
2017 \text { [I4] }\end{array}$} & \multirow{4}{*}{$\begin{array}{c}\text { Using a flexible tape-measure approach in three directions } \\
\text { (preoperative and postoperative measurements of } \mathrm{AB}, \mathrm{BD} \text {, and } \mathrm{CD} \\
\text { were conducted). }{ }^{*}\end{array}$} & \multirow{4}{*}{ 2nd, and 7 th POD } & \multicolumn{5}{|c|}{ Mean (SD) } \\
\hline & & & $\mathrm{BD}$ & $\begin{array}{c}\text { Preop } \\
\text { 2nd POD } \\
\text { 7th POD }\end{array}$ & $\begin{array}{c}8.7 \text { (o.8) } \\
9.5 \text { (I.0) } \\
8.8 \text { (o.8) }\end{array}$ & $\begin{array}{l}8.5(0.8) \\
9.5(0.8) \\
8.7(0.8)\end{array}$ & $\begin{array}{l}0.306^{\ddagger} \\
0.930^{\ddagger} \\
0.408^{\ddagger}\end{array}$ \\
\hline & & & $\mathrm{CD}$ & $\begin{array}{c}\text { Preop } \\
\text { 2nd POD } \\
\text { 7th POD }\end{array}$ & $\begin{array}{c}\text { I0.8 (o.8) } \\
\text { II.3 (o.9) } \\
\text { I0.9 (o.8) }\end{array}$ & $\begin{array}{c}\text { IO. } 8 \text { (0.7) } \\
\text { II.3 (o.7) } \\
\text { I0.8 (o.7) }\end{array}$ & $\begin{array}{l}0.782 \ddagger \\
0.744^{\ddagger} \\
0.845^{\ddagger}\end{array}$ \\
\hline & & & $\mathrm{AB}$ & $\begin{array}{c}\text { Preop } \\
\text { 2nd POD } \\
\text { 7th POD }\end{array}$ & $\begin{array}{r}9.8(0.8) \\
\text { IO.I (o.8) } \\
9.7(\mathrm{I} .3)\end{array}$ & $\begin{array}{c}9.7(0.8) \\
\text { I0.0 (o.7) } \\
9.7(0.8)\end{array}$ & $\begin{array}{l}0.468^{\ddagger} \\
0.778^{\ddagger} \\
0.896^{\ddagger}\end{array}$ \\
\hline $\begin{array}{l}\text { Miyamoto et al., } \\
2020[\mathrm{I} 6]\end{array}$ & VAS & For $7 \mathrm{POD}$ & $\begin{array}{l}\text { Swelling allevi } \\
\text { was not statisti }\end{array}$ & $\begin{array}{l}\text { was slightly } \\
\text { significant. I }\end{array}$ & $\begin{array}{l}\text { in the } P R F \text { \& } \\
\text { s were demo }\end{array}$ & $\begin{array}{l}\text {, although it } \\
\text { ted in figure. }\end{array}$ & $p>0.05$ \\
\hline $\begin{array}{l}\text { Gupta et al., } \\
\text { 202I [I8] }\end{array}$ & $\begin{array}{l}\text { Using a flexible tape-measure approach in two directions } \\
\text { (measurement of } \mathrm{AB} \text { and } \mathrm{CD} \text { on both sides postoperatively. For the } \\
\text { purposes of comparison, the mean of the two was applied). }{ }^{*}\end{array}$ & Ist, 3 rd, and 7 th POD & Mean (SD) & $\begin{array}{l}\text { Ist POD } \\
\text { 3rd POD } \\
\text { 7th POD }\end{array}$ & $\begin{array}{l}2.43(0.28) \\
3.46(0.37) \\
0.19(0.08)\end{array}$ & $\begin{array}{l}2.61(0.31) \\
3.73(0.39) \\
0.23(0.06)\end{array}$ & $\begin{array}{l}0.06 \mathrm{I}^{\ddagger} \\
0.03 \mathrm{I}^{\ddagger} \\
0.08 \mathrm{I}^{\ddagger}\end{array}$ \\
\hline
\end{tabular}

${ }^{*}$ A measuring tape was used to estimate the points A-lateral canthus of the eye, B-angle of the mandible (Gonion), C-tragus of ear, D-angle of the mouth, and distance AB, CD, BD. VAS

$=$ Visual analog scale, Preop = preoperative, $\mathrm{POD}=$ Post-operatative day, $\mathrm{SD}=$ Standard deviation, NR = Not reported, ${ }^{\ddagger} p<0.05$, Statistically significant, ${ }^{\ddagger} p>0.05$, Statistically non-significant. 
Table 5. PRF effect on soft tissue and bone healing of included studies.

\begin{tabular}{|c|c|c|c|c|c|c|c|c|}
\hline \multirow{2}{*}{ Authors, Year } & \multirow{2}{*}{ Study Variables } & \multirow{2}{*}{$\begin{array}{l}\text { Procedure of } \\
\text { Measurement }\end{array}$} & \multirow{2}{*}{$\begin{array}{c}\text { Postoperative } \\
\text { Follow-Up Periods }\end{array}$} & \multicolumn{5}{|c|}{ Results } \\
\hline & & & & \multicolumn{2}{|c|}{ Statistic } & PRF & Control & $p$-Value \\
\hline $\begin{array}{l}\text { Al-Hamed et al., } \\
2017[\mathrm{I} 3]\end{array}$ & Soft tissue healing & Landry et al. healing index & Ist week & \multicolumn{2}{|c|}{ Mean (SD) } & $4.52(0.71)$ & $4.20(0.95)$ & $0.187^{\ddagger}$ \\
\hline Ritto et al., 2019 [I5] & Soft tissue healing & Landry et al. healing index & NR & \multicolumn{2}{|c|}{ NR } & NR & NR & $>0.05^{\ddagger}$ \\
\hline Gupta et al., 202I [18] & Soft tissue healing & Landry et al. healing index & Ist, 3 rd, and 7 th day & Mean (SD) & $\begin{array}{l}\text { Ist POD } \\
\text { 3rd POD } \\
\text { 7th POD }\end{array}$ & $\begin{array}{c}1.7(0.45) \\
3.35(0.57) \\
4.3(0.56) \\
\end{array}$ & $\begin{array}{l}1.45(0.49) \\
2.95(0.66) \\
3.85(0.72) \\
\end{array}$ & $\begin{array}{l}0.10^{\ddagger} \\
0.05^{\ddagger} \\
0.03^{\ddagger}\end{array}$ \\
\hline \multirow{3}{*}{ Kumar et al., 20Is [II] } & \multirow{3}{*}{ Bone healing } & \multirow{3}{*}{ IOPAR and OPG } & \multirow{3}{*}{ Ist and $3 \mathrm{rd}$ month } & \multicolumn{4}{|c|}{ Proportion } & \multirow{3}{*}{$0.083^{\ddagger}$} \\
\hline & & & & Mild to mc & te increase & II $(68.8 \%)$ & $14(93.3 \%)$ & \\
\hline & & & & Sever & rease & $05(31.3 \%)$ & or $(6.7 \%)$ & \\
\hline \multirow[t]{3}{*}{ Baslarli et al., 2015 [19] } & \multirow[t]{3}{*}{ Bone healing } & $\begin{array}{l}\text { OPG (The Image J } \\
\text { software tool was used to } \\
\text { compute the peak MGV) }\end{array}$ & Ist and $3 \mathrm{rd}$ month & \multicolumn{2}{|c|}{ Mean } & \multicolumn{2}{|c|}{ Used figure to express values } & $>0.05^{\ddagger}$ \\
\hline & & \multirow{2}{*}{ Bone scintigraphy } & \multirow{2}{*}{ Ist and 3 rd month } & \multirow{2}{*}{ Mean (SD) } & Ist month & $4.7 \mathrm{I}(\mathrm{I} . \mathrm{I} 6)$ & $4.6(0.95)$ & \multirow{2}{*}{$>0.05^{\ddagger}$} \\
\hline & & & & & 3rd month & 4.I (I.I) & 3.96 (1.0) & \\
\hline Ritto et al., 2019 [I5] & Bone healing & $\begin{array}{l}\text { CBCT (Used medical } \\
\text { image processing program, } \\
\text { ITK-SNAP } 3.0 \text { ) }\end{array}$ & 3rd month & & & $954.10(500.76)$ & $522.51(352.28)$ & $0.007^{\ddagger}$ \\
\hline \multirow{3}{*}{ Gupta et al., 202I [I8] } & \multirow{3}{*}{ Bone healing } & \multirow{3}{*}{$\begin{array}{l}\text { IOPAR (Radiographic } \\
\text { bone densities profiles } \\
\text { assessment using of } \\
\text { Sidexis XG software) }\end{array}$} & \multirow{3}{*}{ Ist, 3rd and 6th month } & \multirow{3}{*}{ Mean (SD) } & Ist month & $18.75(5.17)$ & $13.58(4.87)$ & $0.0023^{\ddagger}$ \\
\hline & & & & & 3rd month & $51.47(3.93)$ & $47.58(3.17)$ & $0.0014^{\ddagger}$ \\
\hline & & & & & 6th month & $77.63(6.97)$ & $70.54(5.76)$ & $0.0012^{\ddagger}$ \\
\hline
\end{tabular}

IOPAR = Introral periapical radiograph, OPG = Orthopantomogram, CBCT = Cone beam computed tomography, MGV = Mean gray values, $\mathrm{SD}=\mathrm{Standard}$ deviation, $\mathrm{NR}=\mathrm{Not}$ reported,

POD $=$ Post-operatve day, ${ }^{\ddagger} p<0.05$, Statistically significant, ${ }^{\ddagger} p>0.05$, Statistically non-significant. 


\section{PRF Effect on Bone Healing}

Postoperative radiographic assessment of the extraction socket using intraoral periapical radiograph (IOPAR) [II,I8], orthopantomogram (OPG) [II,I9], and cone beam computed tomography (CBCT) [I5] was conducted to assess bone healing. Bone scintigraphy was used to assess osteoblastic activity in one trial [19]. Three different measurements of bone density were taken at three different locations, and the mean of the three measurements was used for assessment. Three points were chosen: the alveolar crest posterior to the third molar, the mid-distance between the crests, and the apex. In the case of two-rooted teeth, the same protocol was followed for both roots and then the average was used for assessment [II]. Analysis of bone healing in PRF sites revealed noticeably improved outcomes with statistical significance [15,I8]. Bone healing was not discovered to be significant statistically in the studies which were conducted by Kumar et al. [II] and Baslarli et al. [19]. The PRF effect on bone healing of the included studies is detailed in Table 5 .

\section{PRF Effect on Trismus}

Trismus was determined by evaluating the gap between the incisal edge of upper and lower central incisor teeth during maximum mouth opening [I8]. The inter-incisal distance was determined with the help of a divider and a millimeter scale [II]. On the Ist postoperative day, the inter-incisal distance was considerably higher $(p=0.040)$ in the PRF group relative to the control group [II]. The inter-incisal distance obtained on the third postoperative day was highly significant $(p=0.000 \mathrm{I})$, suggesting that when PRF was used into extracted mandibular third molar socket, mouth opening noticeably increased [I8]. Table 6 details the results of the included studies.

Table 6. The result of studies considered in the analysis of trismus.

\begin{tabular}{|c|c|c|c|c|c|}
\hline \multirow{2}{*}{$\begin{array}{c}\text { Authors, } \\
\text { Year }\end{array}$} & \multirow{2}{*}{ Statistic } & \multicolumn{4}{|c|}{ Results } \\
\hline & & Postoperative Follow-Up Periods & PRF & Control & $p$-Value \\
\hline \multirow{3}{*}{$\begin{array}{c}\text { Kumar et al., } \\
2015 \text { [II] }\end{array}$} & \multirow{3}{*}{ Mean (SD) } & Ist POD & $33.0(\mathrm{I} .592)$ & $31.07(3.195)$ & $0.040^{\ddagger}$ \\
\hline & & Ist month & NR & NR & NR \\
\hline & & 3 rd month & NR & NR & NR \\
\hline \multirow{3}{*}{$\begin{array}{l}\text { Gupta et al., } \\
\text { 202I [18] }\end{array}$} & \multirow{3}{*}{ Mean (SD) } & Ist POD & $37.13(2.52)$ & $35.72(2.36)$ & $0.075^{\ddagger}$ \\
\hline & & 3rdPOD & $35.60(\mathrm{r} .97)$ & 3I. 8 (I.70) & $0.0001^{\ddagger}$ \\
\hline & & 7th POD & $43.10(2.31)$ & $41.7(2.26)$ & $0.60^{\ddagger}$ \\
\hline
\end{tabular}

$\mathrm{POD}=$ Postoperative day, $\mathrm{NR}=$ Not reported, $\mathrm{SD}=$ Standard deviation, ${ }^{\ddagger} p<0.05$, statistically significant, ${ }^{\ddagger} p>0.05$, statistically non-significant.

\section{PRF Effect on Periodontal Pocket Depth}

Kumar et al. [II] employed a UNC is periodontal probe to find the PPD along the distal surface of the second molar at three sites (distobuccal, mid-distal, and distolingual) from the gingival margin to the depth of the socket. The PPD between the first and third months postoperatively was also statistically significant in the PRF group $(p<$ o.ooI) relative to the control group $(p=0.0 \mathrm{I} 4)$, indicating a faster rate of pocket depth reduction in the PRF group. Moreover, the change in the PPD between I- and 3-month postoperative readings in the case group was also meaningful statistically $(p<0.00 \mathrm{I})$ when compared to the control group, implying an accelerated rate of pocket depth reduction in the case group [II]. Baslarli et al. [19] utilized a Michigan periodontal probe to assess the PPD at six points (mid, mesial, and distal parts of the buccal and lingual aspect of the second molar) from the gingival margin to the depth of the socket. At the ist and 3rd month postoperative visits, there was no statistically significant difference in periodontal pocket depth between PRF treated and control patients ( $p<$ o.oI) [19]. Sybil et al. [17] reported reducing PPD in the PRF 
group in comparison to the control group and found statistical significance $(p<0.00 \mathrm{I})$ in the sixth month postoperatively. The PRF effect on the PPD is detailed in Table 7.

Table 7. The result of included studies considered in the analysis of periodontal pocket depth measurement.

\begin{tabular}{|c|c|c|c|c|c|}
\hline \multirow{2}{*}{ Authors, Year } & \multirow{2}{*}{ Statistic } & \multicolumn{4}{|c|}{ Results } \\
\hline & & Follow-Up Periods & PRF & Control & $p$-Value \\
\hline \multirow{3}{*}{$\begin{array}{l}\text { Kumar et al., } \\
\text { 20I5 [II] }\end{array}$} & \multirow{3}{*}{ Mean (SD) } & Pre-operative & $5.94(0.87)$ & $6.09(\mathrm{I} .28)$ & \multirow{3}{*}{$\begin{array}{c}\operatorname{PRF}(p<0.00 I)^{\ddagger} \\
\text { Control }(p=0.014)^{\ddagger}\end{array}$} \\
\hline & & Ist month POD & $4.88(0.64)$ & $5.24(\mathrm{I} .04)$ & \\
\hline & & 3rd month POD & $3.4(0.49)$ & $4.78(\mathrm{I} .2 \mathrm{O})$ & \\
\hline $\begin{array}{l}\text { Baslarli et al., } \\
\text { 2015 [19] }\end{array}$ & NR & $\begin{array}{l}\text { Ist month POD } \\
\text { 3rd month POD }\end{array}$ & NR & NR & $p<\mathrm{o} . \mathrm{OI}^{\ddagger}$ \\
\hline \multirow{3}{*}{$\begin{array}{l}\text { Sybil et al., } \\
2020[17]\end{array}$} & \multirow{3}{*}{ Mean (SD) } & Pre-operative & $\mathrm{I} .32(0.63)$ & $\mathrm{I} .4 \mathrm{I}(0.57)$ & $0.585^{\ddagger}$ \\
\hline & & Ist month POD & $0.65(0.49)$ & $0.83(0.55)$ & $0.229^{\ddagger}$ \\
\hline & & 6th month POD & $0.38(0.44)$ & $0.97(0.47)$ & $<0.00 I^{\ddagger}$ \\
\hline
\end{tabular}

$\mathrm{NR}=$ Not reported, $\mathrm{POD}=$ Postoperative day, $\mathrm{SD}=$ Standard deviation, ${ }^{\ddagger} p<0.05$, statistically significant, ${ }^{\ddagger} p>0.05$, statistically non-significant.

\section{PRF Effect on Analgesic Consumption}

Al-Hamed et al. [13] concluded that, for the second, third, sixth, and seventh postoperative days (the $p$-value was $0.019,0.039,0.045$ and 0.020 , respectively), the PRF group consumed less analgesic (Ibuprofen $400 \mathrm{mg}$ thrice a day as an analgesic for the first day of surgery and in the case of constant pain). For the fourth and fifth postoperative days, no substantial difference was reported [13]. Gupta et al. [I8] found that analgesic usage was significantly reduced $(p=0.004)$ on the third postoperative day in the PRF treated group. The PRF effect on analgesic consumption is detailed in Table 8.

Table 8. The included studies considered in the analysis of analgesic consumption.

\begin{tabular}{|c|c|c|c|c|c|c|}
\hline \multirow{2}{*}{$\begin{array}{c}\text { Authors, } \\
\text { Year }\end{array}$} & \multirow[b]{2}{*}{ Procedure of Measurement } & \multirow[b]{2}{*}{ Statistic } & \multicolumn{4}{|c|}{ Results } \\
\hline & & & $\begin{array}{l}\text { Follow-Up } \\
\text { Periods }\end{array}$ & PRF & Control & $p$-Value \\
\hline $\begin{array}{l}\text { Al-Hamed } \\
\text { et al., 20I7 [I3] }\end{array}$ & $\begin{array}{c}\text { From the } 2 \text { nd to the } 7 \text { th POD the } \\
\text { number of analgesic tablets } \\
\text { consumed. }\end{array}$ & Mean (SD) & $\begin{array}{l}\text { 2nd POD } \\
\text { 3rd POD } \\
\text { 4th POD } \\
\text { 5th POD } \\
\text { 6th POD } \\
\text { 7th POD }\end{array}$ & $\begin{array}{c}\mathrm{I} .32 \text { (I.II) } \\
0.88(\mathrm{o} .88) \\
0.64(\mathrm{o} .75) \\
0.44(\mathrm{o} .58) \\
0.16(0.37) \\
\mathrm{o}(\mathrm{o})\end{array}$ & $\begin{array}{c}2.12(\mathrm{I} .20) \\
\mathrm{I} .4 \mathrm{O}(\mathrm{o} .86) \\
\mathrm{I} .00(0.8 \mathrm{I}) \\
0.84(0.8 \mathrm{O}) \\
0.52(0.7 \mathrm{I}) \\
0.24(0.52)\end{array}$ & $\begin{array}{l}0.019^{\ddagger} \\
0.039^{\ddagger} \\
0.054^{\ddagger} \\
0.070^{\ddagger} \\
0.045^{\ddagger} \\
0.020^{\ddagger}\end{array}$ \\
\hline $\begin{array}{l}\text { Gupta et al., } \\
\text { 202I [I } 8]\end{array}$ & $\begin{array}{l}\text { On postoperative visits, patients were } \\
\text { asked to keep count of the analgesics } \\
\text { they had taken. }\end{array}$ & Mean (SD) & $\begin{array}{l}\text { Ist POD } \\
\text { 3rdPOD } \\
\text { 7th POD }\end{array}$ & $\begin{array}{l}2.25(0.43) \\
1.40(0.49) \\
0.15(0.36)\end{array}$ & $\begin{array}{l}2.5(0.5) \\
1.9(0.54) \\
0.3(0.21)\end{array}$ & $\begin{array}{l}0.09^{\ddagger} \\
0.004^{\ddagger} \\
0.115^{\ddagger}\end{array}$ \\
\hline
\end{tabular}

\section{PRF Effect on Alveolar Osteitis (AO)}

Cheung et al. [22] guidelines were used for evaluating post-extraction socket complications. It consists of three traits for assessing post-extraction socket complications. Firstly, a tender socket with the presence of pus, erythema, and an increased body temperature is confirmed as an acute infection within the socket. Secondly, $\mathrm{AO}$ is diagnosed clinically by the presence of throbbing pain and other associated signs. Finally, acute painful socket without the presence of pus or raising body temperature above normal. Persistent and 
intense pain during the first postoperative week, bad taste, bad breath, regional lymphadenitis, and breakdown of the clot in the extraction socket are all clinical features of $\mathrm{AO}$. The pathogenesis of $\mathrm{AO}$ depends upon multiple factors. All of the elements engaged, however, ultimately lead to the primary blood clot failing to mature. To avoid or manage $\mathrm{AO}$, the goal must always be to promote natural healing. After lower third molar extraction, the topical formulation of PRF considerably reduced the incidence of $\mathrm{AO}(p=0.037)$, reported by Al-Hamed et al. [13]. PRF is a healing biomaterial and causes a considerable difference in the prevalence of AO in the PRF group versus the control group. The author also reported that PRF did not reduce the incidence of infected ( $p=\mathrm{I} . \mathrm{OO})$ and inflamed sockets $(p=0.3 \mathrm{I2})$ [13]. Platelets, leukocytes, cytokines, and immune cells are all stored in the PRF. It is reported to permit gradual cytokine discharge, which is essential for angiogenesis, tissue repair, and cicatrization $[23,24]$. These characteristics may contribute to the production and stability of blood clots, lowering the risk of AO.

\section{Discussion}

In oral surgical procedures, PRF has been employed commonly [2,5]. We reviewed this study to appraise PRF efficiency in post-extraction lower third molar socket healing and complications following surgery. The topical implementation of PRF into extracted alveolar sockets of the lower third molar was completed to achieve better tissue healing and diminish the risk of complications following surgery [II-19]. PRF is an autologous growth factor storage made up of a fibrin network with a three-dimensional form, platelets, leukocytes, and cytokines, as well as the association of endogenous stem cells [25]. Platelets, leukocytes, and cytokines are key elements of this biocompatible substance and the fibrin matrix that maintains them is indispensable in forming the influencing factors that determine PRF's potential beneficial ability [26]. PRF is said to permit the gradual discharge of cytokines such as platelet derived growth factor (PDGF), transforming growth factor (TGF), endothelial growth factor (EGF), and vascular endothelial growth factor (VEGF), all of which are key elements for the development of new blood vessels, tissue repair, and cicatrization $[8,23,24]$. PRF has also been demonstrated to have better immunity and the preservation of damaged tissues by having a beneficial impact on epithelial cells and fibroblasts $[25,26]$. Platelet concentrates have the potential to stimulate osseous and soft tissue regeneration while also reducing inflammation, discomfort, and side effects [I2,24].

PRF processing is a convenient, low-cost procedure that needs no additives. However, quick blood processing is crucial to its effectiveness. Mismanagement of handling the blood sample quickly ends in dispersed polymerized fibrin inside the glass container, yielding only a minor blood clot and little consistency [25]. When a greater amount of blood is utilized for processing, more PRF is collected, which results in a higher quantity of growth factors. After all, the majority of the mentioned experiments employed the identical processing method (Table I). The influence of PRF concentration could not be assessed (Table I) [II-I4,I6,I9]. The blood would be separated into acellular plasma in the upper layer, a PRF layer in the center, and a red blood cell layer in the lowermost stratum after a ten-minute centrifugation cycle at 3,00o rotations per minute [8].

The outcome of PRF on pain, swelling, soft tissue healing, hard tissue healing, mouth opening, and PPD after mandibular third molar extraction was found to be inconsistent in these studies. In only two trials, the impact of PRF on bone healing was illustrated in this review [15,18]. Just one study reported PRF to be efficient in soft tissue healing [18]. The healing mechanism is influenced by the tooth's position and the extraction procedure used, such as bone removal. Bone removal was done to extract the mandibular third molar in all studies except in two trials [12,19]. Just one report reported the risk of $\mathrm{AO}$ following mandibular third molar extraction. It showed a significant lower incidence in $\mathrm{AO}$ in support of PRF [13]. In the majority of the trials mentioned, primary closure was achieved. The key drawbacks of the accessible records were the insufficient sampling sizes of the mentioned trials, except for two trials [12,I3]. Furthermore, articles written in languages 
other than English not included in this review; these studies may have provided important data about the effect of PRF following lower third molar surgery.

\section{Conclusions}

The PRF preparation procedure is easy and less expensive, and the localized implementation of PRF has yielded positive results. Local administration of PRF is an effective way of alleviating pain, trismus, oedema, and enhancing soft tissue healing following lower third molar extraction. PRF tends to have no role in bone healing following extraction of the mandibular third molar. PRF may be suggested for topical application into the sockets, especially for patients experiencing difficult surgical extraction of impacted lower third molars. More controlled clinical trials are needed to investigate the consequences of the PRF application.

Author Contributions: Conceptualization, A.F.M.S.R.; Methodology, A.F.M.S.R.; Software, A.F.M.S.R.; Validation, A.F.M.S.R., T.J.; Formal Analysis, A.F.M.S.R. and T.J.; Data Curation, A.F.M.S.R.; Writing-Original Draft Preparation, A.F.M.S.R.; Writing-Review and Editing, A.F.M.S.R.; Visualization, T.J.; Supervision, A.F.M.S.R.; Project Administration, A.F.M.S.R., T.J.

Funding: This research received no external funding.

Conflicts of Interest: The authors declare no conflict of interest.

\section{References}

I. Fuster-Torres, A.; Gargallo-Albiol, J.; Berini-Aytes, L.; Gay-Escoda, C. Evaluation of the indication for surgical extraction of third molars according to the oral surgeon and the primary care dentist. Experience in the Master of Oral Surgery and Implantology at Barcelona University Dental School. Med. Oral Patol. Oral Cir. Bucal 2oo8, I3, E499-E504. [PubMed]

2. Al-Hamed, F.; Tawfik, M.; Abdelfadil, E.; Al-Saleh, M. Efficacy Of Platelet-Rich Fibrin After Mandibular Third Molar Extraction: A Systematic Review And Meta-Analysis. J. Oral Maxillofac. Surg. 2017, 75, II24-II35. [CrossRef] [PubMed]

3. Antonello, G.; Torres do Couto, R.; Giongo, C.; Corrêa, M.; Chagas Júnior, O.; Lemes, C. Evaluation of the effects of the use of platelet-rich plasma (PRP) on alveolar bone repair following extraction of impacted third molars: Prospective study. J. Cranio-Maxillofac. Surg. 2013, 4I, e70-e75. [CrossRef] [PubMed]

4. Ogundipe, O.; Ugboko, V.; Owotade, F. Can autologous platelet-rich plasma gel enhance healing after surgical extraction of mandibular third molars? J. Oral Maxillofac. Surg. 201I, 69, 2305-2310. [CrossRef]

5. Del Corso, M.; Vervelle, A.; Simonpieri, A.; Jimbo, R.; Inchingolo, F.; Sammartino, G.; Ehrenfest, D.M.D. Current knowledge and perspectives for the use of platelet-rich plasma (PRP) and platelet-rich fibrin (PRF) in oral and maxillofacial surgery part I: Periodontal and dentoalveolar surgery. Curr. Pharm. Biotechnol. 2or2, I3, I207-I230. [CrossRef]

6. Choukroun, J.; Adda, F.; Schoeffler, C.; Vervelle, A. Une opportunite en paro-implantologie: LePRF. Implantodontie 2000, 42, 55-62.

7. Canellas, J.; Medeiros, P.; Figueredo, C.; Fischer, R.; Ritto, F. Platelet-Rich Fibrin In Oral Surgical Procedures: A Systematic Review And Meta-Analysis. Int. J. Oral Maxillofac. Surg. 2o19, 48, 395-414. [CrossRef]

8. Dohan, D.; Choukroun, J.; Diss, A.; Dohan, S.; Dohan, A.; Mouhyi, J.; Gogly, B. Platelet-Rich Fibrin (PRF): A Second-Generation Platelet Concentrate. Part II: Platelet-Related Biologic Features. Oral Surg. Oral Med. Oral Pathol. Oral Rad. Endodontol. 2006, I0I, e45-e5o. [CrossRef]

9. Pirraco, R.; Reis, R.; Marques, A. Effect Of Monocytes/Macrophages On The Early Osteogenic Differentiation Of Hbmscs. J. Tissure Eng. Regen. Med. 2012, 7, 392-400. [CrossRef]

Io. Dohan Ehrenfest, D.; Del Corso, M.; Diss, A.; Mouhyi, J.; Charrier, J. Three-Dimensional Architecture And Cell Composition Of A Choukroun's Platelet-Rich Fibrin Clot And Membrane. J. Periodontol. 2oro, 8I, 546-555. [CrossRef]

II. Kumar, N.; Prasad, K.; Ramanujam, L.; Ranganath, K.; Dexith, J.; Chauhan, A. Evaluation Of Treatment Outcome After Impacted Mandibular Third Molar Surgery With The Use Of Autologous Platelet-Rich Fibrin: A Randomized Controlled Clinical Study. J. Oral Maxillofac. Surg. 2o15, 73, 1042-1049. [CrossRef]

I2. Ozgul, O.; Senses, F.; Er, N.; Tekin, U.; Tuz, H.; Alkan, A.; Kocyigit, I.; Atil, F. Efficacy Of Platelet Rich Fibrin In The Reduction Of The Pain And Swelling After Impacted Third Molar Surgery: Randomized Multicenter Split-Mouth Clinical Trial. Head Face Med. 2015, II, 37-4I. [CrossRef] 
I3. Al-Hamed, F.; Tawfik, M.; Abdelfadil, E. Clinical Effects Of Platelet-Rich Fibrin (PRF) Following Surgical Extraction Of Lower Third Molar. Saudi J. Dent. Res. 2017, 8, 19-25. [CrossRef]

I4. Gülşen, U.; Şentürk, M. Effect Of Platelet Rich Fibrin On Edema And Pain Following Third Molar Surgery: A Split Mouth Control Study. BMC Oral Health 2or7, 17, 79-84. [CrossRef]

I5. Ritto, F.; Pimentel, T.; Canellas, J.; Junger, B.; Cruz, M.; Medeiros, p. Randomized Double-Blind Clinical Trial Evaluation Of Bone Healing After Third Molar Surgery With The Use Of Leukocyte- And Platelet-Rich Fibrin. Int. J. Oral Maxillofac. Surg. 2019, 48, 1088-1093. [CrossRef]

I6. Miyamoto, H.; Nakamura, T.; Takashima, H.; Mizutani, T.; Morita, M.; Hirose, M.; Kurata, M.; Maeda, M.; Aoki, N.; Kato, S.; et al. Investigation of the analgesic effect of platelet-rich fibrin on postoperative pain after mandibular impacted wisdom tooth extraction. J. Oral Maxillofac. Surg. Med. Pathol. 2020, 32, 237-240. [CrossRef]

17. Sybil, D.; Sawai, M.; Faisal, M.; Singh, S.; Jain, V. Platelet-rich fibrin for hard- and soft-tissue healing in mandibular third molar extraction socket. Ann. Maxillofac. Surg. 2020, Io, I02-I07.

I8. Gupta, N.; Agarwal, S. Advanced-PRF: Clinical evaluation in impacted mandibular third molar sockets. J. Stomatol. Oral Maxillofac. Surg. 2021, I22, 43-49. [CrossRef]

19. Baslarli, O.; Tumer, C.; Ugur, O.; Vatankulu, B. Evaluation of osteoblastic activity in extraction sockets treated with platelet-rich fibrin. Med. Oral Patol. Oral Cir. Bucal 2015, 20, enI-eni6. [CrossRef]

20. Pasqualini, D.; Cocero, N.; Castella, A.; Mela, L.; Bracco, P. Primary and secondary closure of the surgical wound after removal of impacted mandibular third molars: A comparative study. Int. J. Oral Maxillofac. Surg. 2oo5, 34, 52-57. [CrossRef]

2I. Landry, R.; Turnbull, R.; Howley, T. Effectiveness of benzydamine HCL in the treatment of peridontal post-surgical patients. Res. Clin. Forums 1988, I0, I05-II8.

22. Cheung, L.; Chow, L.; Tsang, M.; Tung, L. An evaluation of complications following dental extractions using either sterile or clean gloves. Int. J. Oral Maxillofac. Surg. 2oor, 30, 550-554. [CrossRef] [PubMed]

23. Dohan, D.; Choukroun, J.; Diss, A.; Dohan, S.; Dohan, A.; Mouhyi, J. Platelet-rich fibrin (PRF): A second-generation platelet concentrate. part I: Technological concepts and evolution. Oral Surg. Oral Med. Oral Pathol. Oral Radiol. Endodontol. 2006, I0I, e37-e44. [CrossRef] [PubMed]

24. Choukroun, J.; Diss, A.; Simonpieri, A.; Girard, M.; Schoeffler, C.; Dohan, S. Platelet-Rich Fibrin (PRF): A Second-Generation Platelet Concentrate. Part IV: Clinical Effects On Tissue Healing. Oral Surg. Oral Med. Oral Pathol. Oral Radiol. Endodontol. 2006, I0I, e56-e6o. [CrossRef]

25. Jayadev, M.; Marshal, V.; Naik, B.; Karunakar, P. Role Of Platelet Rich Fibrin In Wound Healing: A Critical Review. J. Conserv. Dent. 2013, I6, 284-293. [CrossRef]

26. Warraich, R.; Faisal, M.; Rana, M.; Shaheen, A.; Gellrich, N.; Rana, M. Evaluation of postoperative discomfort following third molar surgery using submucosal dexamethasone-A randomized observer blind prospective study. Oral Surg. Oral Med. Oral Pathol. Oral Radiol. 2013, $116,16-22$. [CrossRef]

${ }^{\circ}$ 202I Copyright by the author. Licensed as an open access article using a CC BY 4.0 license.

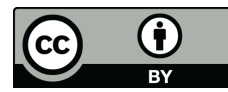

